\title{
HUBUNGAN ANTARA DERAJAT SINDROM PRAMENSTRUASI DAN AKTIVITAS FISIK DENGAN PERILAKU MAKAN PADA REMAJA PUTRI
}

\author{
Rosa Pratita, Ani Margawati ${ }^{*}$ \\ Program Studi Ilmu Gizi Fakultas Kedokteran Universitas Diponegoro \\ Jl.Dr.Sutomo No.18, Semarang, Telp (024) 8453708, Email : gizifk@undip.ac.id
}

\begin{abstract}
Background : Adolescence was a time of puberty. Puberty in girls was characterized by the occurrence of menstruation. Menstruation was accompanied by premenstrual syndrome will affect the quality of life for young women. This study aimed to determine the relationship between premenstrual syndrome and physical activity with eating behaviour in adolescent girls.

Methods : This study was an observational study used cross-sectional design. The subjects were 63 students of class VII and VIII SMP PL Domenico Savio who were selected consecutively. Data premenstrual syndrome was obtained by SPAF (Shortened Premenstrual Assessment Form). Data on physical activity was obtained by 24-h physical activity questionnaire from WHO. Data on eating behaviour was obtained through Semi-Quantitative Food Frequency Questionnaire with several additional questions. Data were analyzed using chi-square test .

Results : The majority ( $96.8 \%$ ) subjects had mild premenstrual syndrome, $66.7 \%$ of the subjects had moderate activity and $52.4 \%$ of the subjects had good eating behaviour. There was no relationship between premenstrual syndrome with eating behaviour in adolescent girls $(p=0.132)$. There was no relationship between physical activity with eating behaviour in adolescent girls $(p=0.593)$

Conclusions : There was no relationship between premenstrual syndrome with eating behaviour in adolescent girls. There was no relationship between physical activity with eating behaviour in adolescent girls.

Keywords : premenstrual syndrome; physical activity; eating behaviour; adolescent girl
\end{abstract}

\section{ABSTRAK}

Latar Belakang : Masa remaja merupakan masa terjadinya pubertas. Pubertas pada remaja putri ditandai dengan terjadinya menstruasi. Menstruasi yang disertai sindrom pramenstruasi akan mempengaruhi kualitas hidup remaja putri. Penelitian ini bertujuan untuk mengetahui hubungan antara derajat sindrom pramenstruasi dan aktivitas fisik dengan perilaku makan pada remaja putri.

Metode : Penelitian ini merupakan penelitian observasional dengan rancangan cross sectional. Subjek terdiri dari 63 siswi kelas VII dan VIII SMP PL Domenico Savio yang dipilih secara consecutive. Data sindrom pramenstruasi diperoleh dari SPAF (Shortened Premenstrual Assessment Form). Data aktivitas fisik diperoleh dari kuesioner aktivitas fisik 24jam dari WHO. Data perilaku makan diperoleh melalui kuesioner frekuensi makanan semi kuantitatif dengan beberapa pertanyaan tambahan. Data dianalisis menggunakan uji chi-square.

Hasil : Sebagian besar (96.8\%) subjek memiliki sindrom pramenstruasi ringan, 66.7\% subjek memiliki aktivitas sedang dan 52.4\% subjek memiliki perilaku makan yang baik. Tidak terdapat hubungan antara derajat sindrom pramenstruasi dengan perilaku makan pada remaja putri $(p=0.132)$. Tidak terdapat hubungan antara aktivitas fisik dengan perilaku makan pada remaja putri $(p=0.593)$

Simpulan : Tidak terdapat hubungan antara derajat sindrom pramenstruasi dengan perilaku makan pada remaja putri. Tidak terdapat hubungan antara aktivitas fisik dengan perilaku makan pada remaja putri.

Kata kunci : sindrom pramentruasi; aktivitas fisik; perilaku makan; remaja putri

\section{PENDAHULUAN}

Masa remaja merupakan masa yang penting karena masa ini adalah masa peralihan ke masa dewasa. Masa remaja merupakan suatu fase perkembangan yang dinamis dalam kehidupan seorang individu terutama wanita. Pada masa ini, terjadi proses transisi dari masa anak ke masa dewasa yang ditandai dengan percepatan perkembangan fisik, mental, emosional dan sosial serta berlangsung pada dekade kedua masa kehidupan ${ }^{1}$. Pada masa remaja, seorang anak perempuan akan mengalami pubertas yang ditandai dengan konsepsi yaitu menarche ${ }^{2}$.

Setiap bulannya, wanita usia subur akan mengalami menstruasi. Sebelum terjadinya menstruasi, selama 7- 10 hari seorang wanita akan mengalami gejala-gejala perubahan emosional maupun fisik atau yang sering disebut sindrom pramenstruasi dan akan mereda ketika menstruasi dimulai ${ }^{3}$. Berbagai faktor gaya hidup menjadikan gejala-gejala dari PMS (Premenstrual Syndrome) ini semakin buruk ${ }^{4}$. Namun awal kejadian, durasi dan gejalanya bervariasi pada setiap wanita ${ }^{5}$.

\footnotetext{
${ }^{*}$ Penulis Penanggungjawab
} 
Studi epidemiologi tahun 2007 menunjukkan bahwa 5-10 \% wanita kelompok usia reproduksi dari populasi yang diteliti, mengalami gejala-gejala sementara bersifat sedang sampai berat yang berkaitan dengan siklus menstruasi ${ }^{6}$. Prevalensi sindrom pramenstruasi di beberapa daerah di Indonesia menunjukkan hasil yang berbeda. Penelitian yang dilakukan terhadap siswi SMK di Jakarta Selatan menunjukkan $45 \%$ siswi mengalami sindrom pramenstruasi ${ }^{3}$. Penelitian yang dilakukan di Kudus didapatkan bahwa prevalensi PMS pada mahasiswi Akademi Kebidanan sebanyak $45,8 \%{ }^{7}$. Penelitian yang dilakukan di Padang menunjukkan 51,8\% siswi SMA mengalami sindrom pramenstruasi ${ }^{8}$, sedangkan penelitian yang dilakukan di Purworejo pada siswi sekolah menengah atas, prevalensi sindrom pramenstruasi sebanyak $24,6 \%{ }^{9}$. Berdasarkan penelitian yang dilakukan di Semarang tahun 2003 didapatkan prevalensi kejadian sindrom pramenstruasi sebanyak $24,9 \%{ }^{10}$.

Berdasarkan etiologi, faktor pemicu terjadinya sindrom pramenstruasi belum dapat disimpulkan dengan pasti. Beberapa penelitian menemukan bahwa sindrom pramenstruasi terjadi akibat ketidakseimbangan hormon estrogen dan progesteron. Penelitian lain juga menyebutkan bahwa defisiensi endorfin dalam tubuh dapat mengakibatkan sindrom pramenstruasi, namun dengan aktivitas fisik berupa olahraga dapat merangsang hormon endorfin keluar dan menimbulkan perasaan tenang saat sindrom pramenstruasi terjadi ${ }^{11}$. Patofisiologi sindrom pramenstruasi pun masih dalam penelitian ${ }^{12}$.

Gejala-gejala yang timbul menjelang menstruasi akan menjadi gangguan terhadap aktivitas sehari-hari remaja putri hingga saat menstruasi berlangsung ${ }^{11}$. Sekitar 5-10\% wanita menderita PMS yang berat, mengganggu kegiatan sehari-harinya. Sindrom pramenstruasi pun berdampak pada perubahan nafsu makan dan asupan makan hingga berujung pada perubahan perilaku makan remaja putri. Asupan makan yang berlebih berkaitan dengan kondisi psikologis remaja putri. Perubahan suasana hati dan keinginan makan mengindikasikan kemungkinan makan yang berlebih pada wanita dengan sindrom pramenstruasi dan akan berdampak pada perubahan berat badan ${ }^{13}$. Tingkat keparahan sindrom pramenstruasi memiliki hubungan yang signifikan dengan perubahan konsumsi nutrisi ${ }^{14}$. Hal ini akan berdampak pada kualitas hidup dan produktivitas kerja remaja putri.
Berdasarkan latar belakang tersebut, maka tujuan dari penelitian ini adalah untuk mengetahui hubungan antara derajat sindrom pramenstruasi dan aktivitas fisik dengan perilaku makan pada remaja putri.

\section{METODE}

Penelitian ini dilakukan pada bulan Juli 2013 di SMP PL Domenico Savio Semarang dengan ruang lingkup keilmuan gizi masyarakat. Penelitian ini merupakan penelitian observasional dengan rancangan cross sectional. Populasi dalam penelitian ini adalah siswi kelas VII dan VIII SMP PL Domenico Savio Semarang dengan jumlah responden 63 siswi. Responden penelitian ini didapat dari populasi yang ada yang dipilih secara consecutive sampling dengan kriteria remaja putri berusia 12-15 tahun, sudah mengalami menstruasi, tidak memiliki kelainan reproduksi dan hadir saat penelitian berlangsung.

Data yang dikumpulkan dalam penelitian ini meliputi identitas sampel, data sindrom pramenstruasi, aktivitas fisik dan perilaku makan. Variabel bebas dalam penelitian ini adalah derajat sindrom pramenstruasi dan aktivitas fisik, sedangkan variabel terikat dalam penelitian ini adalah perilaku makan. Data sindrom pramenstruasi diperoleh dari formulir SPAF (Shortened Premenstrual Assessment Form) dan dikelompokkan menjadi ringan, sedang (skor > 30) dan berat (skor $=60$ ). Data aktivitas fisik diperoleh dari formulir kuesioner aktivitas fisik 24jam dari WHO dan dikelompokkan menjadi 3 tingkat yaitu ringan, sedang dan berat. Data perilaku makan diperoleh melalui kuesioner perilaku makan dan dikategorikan menjadi sesuai jika total skor $\geq$ mean skor $\mathrm{T}$ (skor standar) dan tidak sesuai jika total skor < mean skor $\mathrm{T}$ (skor standar).

Pengolahan dan analisis data menggunakan sistem komputerisasi. Analisis univariat untuk mendeskripsikan karakteristik subjek meliputi umur, umur menarche, lama menstruasi, lama gejala sindrom pramenstruasi dan riwayat sindrom pramenstruasi. Analisis bivariat menggunakan uji chi-square dengan $\alpha 0.05$ untuk mengetahui hubungan derajat sindrom pramenstruasi dengan perilaku makan dan hubungan aktivitas fisik dengan perilaku makan.

\section{HASIL PENELITIAN \\ Karakteristik subjek penelitian}

Subjek penelitian ini berjumlah 63 orang siswi. Subjek dikelompokkan menurut usia, usia 
menarche, riwayat sindrom pramenstruasi, uang jajan, lama menstruasi dan lama gejala sindrom

pramenstruasi. Data karakteristik subjek dapat dilihat pada Tabel 1 dan 2.

Tabel 1. Karakteristik subjek berdasarkan usia, usia menarche, riwayat sindrom pramenstruasi

\begin{tabular}{lcc}
\hline \multicolumn{1}{c}{ Karakteristik } & $\mathrm{N}$ & $\%$ \\
\hline Usia & & \\
Remaja awal (12-14 tahun) & 61 & 96.8 \\
Remaja madya (15-17 tahun) & 2 & 3.2 \\
\hline Total & 63 & 100.0 \\
\hline Usia menarche & & \\
9 tahun & 1 & 1.6 \\
10 tahun & 5 & 7.9 \\
11 tahun & 22 & 34.9 \\
12 tahun & 28 & 44.4 \\
13 tahun & 7 & 11.1 \\
\hline Total & 63 & 100.0 \\
\hline Riwayat sindrom & & \\
pramenstruasi keluarga & & \\
Ya & 24 & 38.1 \\
Tidak & 39 & 61.9 \\
\hline Total & 63 & 100.0 \\
\hline
\end{tabular}

Sebagian besar $(96.8 \%)$ subjek berada pada usia remaja awal yang merupakan siswi kelas VII, sedangkan 3.2\% merupakan siswi kelas VIII. Sebagian besar subjek $(44,4 \%)$ mengalami menstruasi pertama kali (menarche) pada usia 12 tahun. Remaja yang memiliki riwayat sindrom pramenstruasi keluarga yaitu $38.1 \%$ dan rata-rata diturunkan dari ibu dan kakak.

Tabel 2. Karakteristik subjek berdasarkan lama menstruasi dan lama gejala sindrom

\begin{tabular}{lccc}
\multicolumn{4}{c}{ pramenstruasi } \\
\hline \multicolumn{1}{c}{ Karakteristik } & Min & Max & Mean(SD) \\
\hline $\begin{array}{l}\text { Lama menstruasi (hari) } \\
\text { Lama gejala sindrom }\end{array}$ & 3 & 14 & $6.11 \pm 1.985$ \\
pramenstruasi (hari) & & 12 & $1.90 \pm 2.161$ \\
\hline
\end{tabular}

Berdasarkan tabel diatas diketahui bahwa rerata lama menstruasi yang dialami remaja putri adalah $6.11 \pm 1.985$ hari dan siklus menstruasi paling lama adalah 14 hari. Gejala sindrom pramenstruasi yang dialami paling lama adalah 12 hari dengan rerata $1.90 \pm 2.161$ hari.

Tabel 3. Karakteristik subjek berdasarkan derajat sindrom pramenstruasi

\begin{tabular}{lcc}
\hline \multicolumn{1}{c}{ Derajat Sindrom Pramenstruasi } & Frekuensi & $\%$ \\
\hline Ringan & 61 & 96.8 \\
Sedang (skor > 30) & 2 & 3.2 \\
\hline Total & 63 & 100.0 \\
\hline
\end{tabular}

Sindrom pramenstruasi ringan dialami 96.8\% remaja putri dengan gejala yang jarang dirasakan dan tidak ada remaja putri yang mengalami sindrom pramenstruasi berat. Gejala yang paling sering dikeluhkan adalah gejala emosional (mudah tersinggung).

Tabel 4. Karakteristik Subjek berdasarkan tipe aktivitas fisik

\begin{tabular}{lccc}
\hline & Tipe aktivitas fisik & Frekuensi & $\%$ \\
\hline Ringan & 21 & 33.3 \\
Sedang & 42 & 66.7 \\
\hline Total & 63 & 100.0 \\
\hline
\end{tabular}


Kategori aktivitas fisik dibagi menjadi 3 yaitu ringan, sedang dan berat. Hasil penelitian menunjukkan bahwa remaja putri dengan aktivitas fisik sedang memiliki persentase paling tinggi yaitu $66.7 \%$ yang artinya $40 \%$ waktu digunakan untuk duduk atau berdiri dan $60 \%$ waktu digunakan untuk melakukan pekerjaan sesuatu dan tidak ada remaja putri yang termasuk dalam aktivitas fisik berat

\section{Perilaku Makan}

Perilaku makan merupakan respon kebiasaan remaja terhadap konsumsi makanan sehari-hari. Dalam penelitian ini, perilaku makan merupakan kebiasaan remaja putri dalam memilih dan mengonsumsi makanan mencakup jenis, jumlah dan frekuensi dalam mengonsumsi makanan.

Tabel 5. Distribusi Perilaku Makan Remaja Putri

\begin{tabular}{|c|c|c|}
\hline Perilaku Makan & frekuensi & $\%$ \\
\hline Sesuai & 33 & 52.4 \\
\hline Tidak sesuai & 30 & 47.6 \\
\hline Total & 63 & 100.0 \\
\hline
\end{tabular}

Berdasarkan tabel 5, dapat diketahui bahwa $52.4 \%$ (33 orang) remaja putri memiliki perilaku makan yang sesuai dan $47.6 \%$ (30 orang) remaja putri memiliki perilaku makan yang tidak sesuai.

\section{Hubungan antara Derajat Sindrom \\ Pramenstruasi dengan Perilaku makan}

Tabel 6. Derajat sindrom pramenstruasi berdasarkan perilaku makan

\begin{tabular}{|c|c|c|c|c|c|}
\hline \multirow{3}{*}{$\begin{array}{c}\text { Variabel } \\
\text { Derajat sindrom } \\
\text { pramenstruasi }\end{array}$} & \multicolumn{4}{|c|}{ Perilaku makan } & \multirow[t]{3}{*}{$p$} \\
\hline & \multicolumn{2}{|c|}{ Tidak Sesuai } & \multicolumn{2}{|c|}{ Sesuai } & \\
\hline & $\mathrm{N}$ & $\%$ & $\mathrm{~N}$ & $\%$ & \\
\hline Ringan & 28 & 45.9 & 33 & 54.1 & 0.132 \\
\hline Sedang & 2 & 100.0 & 0 & 0.0 & \\
\hline
\end{tabular}

Berdasarkan hasil analisis bivariat yang berada pada tabel 6 , diketahui bahwa tidak ada hubungan yang bermakna antara derajat sindrom pramenstruasi dengan perilaku makan yang ditunjukkan dengan $p=0.132$. Sebagian besar $(54.1 \%)$ remaja putri dengan derajat sindrom pramenstruasi ringan memiliki perilaku makan yang sesuai dan 2 remaja putri dengan derajat sindrom pramenstruasi sedang memiliki perilaku makan yang tidak sesuai.

Hubungan antara aktivitas fisik dengan perilaku makan

Tabel 7. Aktivitas fisik berdasarkan perilaku makan

\begin{tabular}{|c|c|c|c|c|c|}
\hline \multirow{3}{*}{$\begin{array}{c}\text { Variabel } \\
\text { Aktivitas fisik }\end{array}$} & \multicolumn{4}{|c|}{ Perilaku makan } & \multirow{3}{*}{$P$} \\
\hline & \multicolumn{2}{|c|}{ Tidak sesuai } & \multicolumn{2}{|c|}{ Sesuai } & \\
\hline & $\mathrm{N}$ & $\%$ & $\mathrm{~N}$ & $\%$ & \\
\hline Ringan & 9 & 42.9 & 12 & 57.1 & 0.593 \\
\hline Sedang & 21 & 50.0 & 21 & 50.0 & \\
\hline
\end{tabular}

Berdasarkan hasil analisis bivariat yang berada pada tabel 7, diketahui bahwa tidak ada hubungan yang bermakna antara aktivitas fisik dengan perilaku makan yang ditunjukkan dengan $p$ $=0.593$. Sebagian besar $(57.1 \%)$ remaja putri dengan aktivitas fisik ringan memiliki perilaku makan yang sesuai dan 50\% remaja putri dengan aktivitas fisik sedang memiliki perilaku makan yang sesuai dan tidak sesuai.

\section{PEMBAHASAN}

Masa remaja (12-21 tahun) merupakan masa yang penting karena masa ini adalah masa peralihan ke masa dewasa. Masa remaja, seseorang mengalami perubahan jasmani yang sangat pesat dan perkembangan intelektual yang sangat intensif sehingga minat anak pada dunia luar sangat besar dan tidak mau dianggap anak-anak lagi. Pada usia ini (12-15 tahun), seorang remaja putri akan 
mengalami pubertas. Pubertas akan berlangsung kurang lebih selama 4 tahun. ${ }^{15}$

Masa pubertas merupakan masa transisi antara masa anak dan dewasa yang lebih ditekankan pada proses biologis dimana terjadi percepatan pertumbuhan (growth spurt), timbul ciri-ciri seksualitas sekunder, tercapai fertilitas (menarche) dan perubahan psikologis ${ }^{1}$. Tanda yang menunjukkan bahwa remaja putri sudah mencapai pubertas adalah terjadinya menstruasi awal (menarche). Rata-rata usia menarche pada penelitian ini terjadi pada golongan usia anakanak atau belum menginjak remaja yaitu kurang dari 12 tahun.

Waktu menstruasi paling lama adalah 14 hari, rata-rata lama menstruasi pada wanita berkisar antara 3-5 hari dan sebagian ada yang 7-8 hari. Apabila darah menstruasi keluar dalam jumlah banyak setiap harinya dalam jangka waktu lebih dari 7 hari, maka hal ini merupakan gejala menoragia. Menoragia merupakan pendarahan yang berlebihan dan terlalu lama pada menstruasi yang teratur.

\section{Hubungan antara Derajat Sindrom Pramenstruasi dengan Perilaku Makan pada Remaja Putri}

Sindrom pramenstruasi merupakan sekumpulan gejala fisik dan psikologis yang secara teratur terjadi pada masa luteal dan berakhir ketika siklus menstruasi berakhir. ${ }^{16}$ Gejala-gejala yang terjadi berupa keluhan fisik (sakit kepala, nyeri punggung, nyeri perut), keluhan psikis (mudah tersinggung, cemas, perubahan suasana hati) dan keluhan perilaku (mudah lelah, sulit tidur). ${ }^{17}$ Gejala tersebut biasanya terjadi 1-2 minggu sebelum menstruasi dimulai. Beberapa penelitian menunjukkan bahwa gejala paling sering terjadi pada sebagian besar wanita adalah keluhan psikis seperti mudah tersinggung. ${ }^{3}$

Gejala-gejala dari sindrom pramenstruasi selalu dihubungkan dengan pola makan remaja putri. Beberapa penelitian menunjukkan bahwa pola makan rendah serat, tinggi gula, rendah magnesium dan kalsium terjadi pada remaja putri yang mengalami sindrom pramenstruasi. Pola makan dengan tinggi gula, rendah serat dan rendah magnesium dan kalsium dapat meningkatkan keluhan pada sindrom pramenstruasi ${ }^{3}$.

Gejala-gejala emosional secara tidak langsung akan mempengaruhi nafsu makan wanita melalui mekanisme hormonal dan neurotransmitter di otak. Namun hal tersebut berbeda dengan hasil yang ditunjukkan dalam penelitian ini, 3.2\% remaja putri mengalami sindrom pramenstruasi sedang, tidak mengalami perubahan nafsu makan sehingga tidak berpengaruh terhadap perilaku makan.

Penyebab dari sindrom pramenstruasi belum diketahui secara pasti. Ada yang menyebutkan sindrom pramenstruasi terjadi karena ketidakseimbangan hormon progesteron dan estrogen, perubahan efek-efek steroid ovarium terhadap sistem saraf pusat dan perubahan sintesis serotonin selama fase luteal yang berpengaruh pada nafsu makan. ${ }^{18}$ Namun beberapa penelitian menunjukkan bahwa sebagian besar wanita yang mengalami gejala emosional saat sindrom pramenstruasi disebabkan oleh ketidakseimbangan hormon estrogen dan progesteron yang berdampak pada neurotransmitter serotonin dan GABA yang mengatur nafsu makan dan perilaku makan.

Mekanisme hormonal dan neurotransmitter yang menjadi penyebab terjadinya sindrom pramenstruasi melibatkan beberapa hormon seperti estrogen, progesteron, leptin, serotonin dan neurotransmitter GABA. Hipotalamus sebagai pusat dari pengaturan aktivitas tubuh termasuk seksualitas dan penurunan stress dapat mempengaruhi kadar hormon estrogen dan progesteron. Pada fase folikuler yang ditandai dengan terjadinya menstruasi, kadar FSH meningkat dan kadar estrogen serta progesteron menurun. Pada fase selanjutnya yaitu fase luteal, LH (Luteinizing Hormon) akan menyebabkan sel granulosa dari folikel membentuk corpus luteum sehingga menghasilkan progesteron dalam jumlah besar dan estrogen dalam jumlah kecil. Pada wanita yang mengalami sindrom pramenstruasi terjadi ketidakseimbangan hormon estrogen dan progesteron, dimana kadar estrogen meningkat dan kadar progesteron menurun sehingga terjadi penurunan sintesis serotonin yang berpengaruh pada perubahan suasana hati dan perilaku. Penurunan sintesis serotonin ini banyak ditemukan pada wanita dengan sindrom pramenstruasi yang mengalami gejala emosional sehingga berpengaruh pada nafsu makannya. Adanya pengaruh terhadap nafsu makan maka akan berdampak pada perilaku makannya. Penurunan kadar progesteron juga akan mempengaruhi neurotransmitter GABA (gammaaminobutyric acid) di otak yang terlibat dalam pengaturan emosi, suasana hati dan perilaku makan. Penurunan sintesis serotonin dan GABA ini melalui mekanismenya akan menurunkan nafsu makan wanita ketika sindrom pramenstruasi terjadi. ${ }^{19}$

Hormon lain yang juga berpengaruh terhadap nafsu makan dan metabolisme tubuh adalah hormon leptin. Hormon leptin juga 
mengatur reproduksi dan emosi sehingga berkaitan dengan terjadinya sindrom pramenstruasi. Wanita yang mengalami sindrom pramenstruasi memiliki kadar leptin yang tinggi selama siklus menstruasi. Mereka cenderung makan makanan yang mengandung tinggi lemak, tinggi gula dan rendah protein. Perubahan neurotransmitter dan interaksinya dengan hormon dapat mengakibatkan terjadinya overweight dan obesitas. Pada beberapa penelitian obesitas menjadi salah satu faktor risiko terjadinya sindrom pramenstruasi. ${ }^{19}$

Berdasarkan penelitian pada 20 wanita dewasa muda menunjukkan bahwa asupan energi dan derajat sindrom pramenstruasi memiliki hubungan yang positif yaitu asupan energi yang tinggi terjadi pada wanita dengan sindrom pramenstruasi berat. $^{20}$ Beberapa penelitian menunjukkan sindrom pramenstruasi berat banyak ditemukkan pada wanita dewasa dengan rentang usia 22-35 tahun.

\section{Hubungan antara aktivitas fisik dengan perilaku makan pada remaja putri}

Adanya gejala sindrom pramenstruasi pada setiap wanita berbeda-beda, beberapa wanita mengalaminya tidak secara terus menerus, ada juga yang bulan berikutnya tidak terasa gejalanya. Adanya sindrom pramenstruasi ini akan sangat mengganggu aktivitas sehari-hari wanita. Beberapa penelitian menyebutkan bahwa derajat sindrom pramenstruasi yang semakin tinggi akan sangat mempengaruhi aktivitas fisik terutama kegiatan sehari-hari wanita.

Aktivitas fisik merupakan kegiatan sehari-hari dan olahraga yang dilakukan oleh remaja putri ${ }^{21}$. Kategori aktivitas fisik dibagi menjadi 3 yaitu ringan, sedang dan berat. Pengelompokkan aktivitas fisik didasarkan pada beban kerja masingmasing. Beban kerja ringan meliputi aktivitas sekolah dan aktivitas lain yang tidak menguras tenaga, beban kerja sedang meliputi aktivitas sekolah disertai dengan pekerjaan rumah tangga dan olahraga, dan beban kerja berat meliputi pekerjaan di lapangan. ${ }^{22}$

Pada penelitian ini aktivitas fisik akibat sindrom pramenstruasi tidak memiliki hubungan yang bermakna dengan perilaku makan pada remaja putri. Hasil uji menunjukkan remaja putri dengan aktivitas fisik yang sedang, sebanyak 50\% memiliki perilaku makan yang baik dan $50 \%$ perilaku makan yang tidak baik. Oleh karena itu perilaku makan tidak dipengaruhi oleh adanya aktivitas fisik ringan maupun sedang. Hasil tersebut berbeda dengan penelitian pada 26 wanita dengan rentang usia 22-39 tahun yang menunjukkan bahwa frekuensi aktivitas fisik memiliki hubungan yang negatif dengan peningkatan asupan makan, yang artinya semakin tinggi frekuensi aktivitas fisiknya maka nafsu makannya akan menurun ${ }^{23}$. Penurunan nafsu makan terjadi akibat aktivitas fisik yang berat merangsang pelepasan hormon ghrelin yang dapat menahan keinginan untuk makan sehingga dapat menurunkan nafsu makan. ${ }^{24}$ Perubahan nafsu makan ini berkaitan erat dengan gejala sindrom pramenstruasi.

\section{SIMPULAN}

Mayoritas perilaku makan remaja putri dalam kategori yang baik. Selain itu derajat sindrom pramenstruasi mayoritas dalam kategori ringan dan aktivitas fisik dalam kategori sedang. Tidak terdapat hubungan antara derajat sindrom pramenstruasi dan aktivitas fisik dengan perilaku makan pada remaja putri.

\section{UCAPAN TERIMA KASIH}

Penulis mengucapkan terima kasih kepada seluruh siswi dan guru SMP PL Domenico Savio atas kerjasama dan partisipasinya dalam penelitian ini. Terima kasih penulis sampaikan kepada Dra. Ani Margawati, M.Kes, Ph.D selaku pembimbing dan para penguji, Prof. dr.H.M.Sulchan. MSc, DA Nutr, SpGK dan Nuryanto, S.Gz, M.Gizi atas kritik dan saran yang telah diberikan dan terima kasih juga penulis sampaikan kepada kedua orang tua dan teman-teman yang telah membantu untuk kelancaran dalam proses penelitian ini.

\section{DAFTAR PUSTAKA}

1. Pardede, Nancy. Masa Remaja dalam Tumbuh Kembang Anak dan Remaja Buku Ajar I. Jakarta: Sagung Seto. Ed I, 2002:138, 169.

2. Sayogo, Savitri. 2006. Gizi Remaja Putri. Jakarta: Balai Penerbit FKUI.

3. Devi, Mazarina. Hubungan Kebiasaan Makanan dengan Kejadian Sindrom Pramenstruasi pada Remaja Putri, Teknologi dan Kejuruan vol 32, No 2, September 2009:197-208.

4. Anthony, Ian. Sindroma Pra-haid, Wanita dan Nutrisi. Health Media Nutrition Series; 2002.

5. Mc Kinley Health Center University of Illinoisat Urbana-Champaign. Nutrition and Premenstrual syndrome. 2008.

6. Freemen, E, W. 2007. Epidemiology and Etiology of Premenstrual Syndromes: Etiology. Dalam Medscape Multispecialty Education. Avalaible from: http://www.medscape.org. Diakses tanggal 31 Mei 2013

7. Puspitorini, Mohammad Hakim dan Emilia O. Obesitas sebagai Faktor Risiko Terjadinya 
Premenstrual Syndrome pada Mahasiswa Akademi Kebidanan Pemerintah Kabupaten Kudus. Berita Kedokteran Masyarakat, Vol. 23, No. 1, Maret 2007.

8. Siantina, Ressa. 2010. Hubungan antara Asupan Zat Gizi dan Aktivitas Olahraga dengan Kejadian Premenstrual Syndrome (PMS) pada Remaja Putri di SMAN 1 Padang [skripsi]. Universitas Andalas; 2010.

9. Nurmiaty. Perilaku Makan dengan Kejadian Sindrom Premenstruasi pada Remaja di Kabupaten Purworejo [tesis]. Universitas Gajah Mada; 2009.

10. Supriyono, B. Hubungan Indeks Massa Tubuh dengan Sindroma Prahaid. Bagian / SMF Obstetri Ginekologi Fakultas Kedokteran Universitas Diponegoro; 2003.

11. Tambing, Yane. Aktivitas Fisik dan Sindrom Premenstruasi pada Remaja [tesis]. Universitas Gajah Mada; 2012.

12. Chocano-Bedoya, et al. Dietary B Vitamin Intake and Incident Premenstrual Syndrome. Am J Clin Nutr 2011;93:1080-6

13. Dye, L dan J.E Blundell. Menstrual cycle and appetite control: implications for weight regulation. Human Reproduction vol. 12 no. 6 pp 1142-51, 1997.

14. Bryant, M, K.P Truesdale dan Dye, L. Modest Changes in Dietary Intake Across the Menstrual Cycle: Implications for Food Intake Research. $\mathrm{Br} \mathrm{J}$ Nutr 2006; 96: 888-94.

15. Shaliha, H. Hubungan Indeks Massa Tubuh (IMT) dengan Usia Menarche pada Remaja Putri di Kecamatan Secanggang, Kabupaten Langkat [skripsi]. Medan. 2010.

16. Myint, T., Ore-Giron, E.D and Sawhsarka, P. Premenstrual Syndrome among Female University Students in Thailand, 2006; AU J.T, 9:158-62.

17. Andrews, G. 2009. Buku Ajar Kesehatan Reproduksi Wanita. Jakarta: EGC

18. Hillegas, K B. Gangguan Sistem Reproduksi Perempuan. Dalam Buku: Patofisiologi: Konsep Klinis Proses-Proses Penyakit.Jakarta:Penerbit Buku Kedokteran EGC; 2006:1287-88.

19. Arem, Ridha. Premenstrual Syndrome and Menopause. Dalam buku : The Thyroid Solution: A Revolutionary Mind-Body Program for Regaining Your Emotional and Physical Health. USA: Ballantine Books; 2007.11.195-6

20. Giannini, A.J., Price, W.A., Loiselle, R.H. and Giannini, M.C. Hyperphagia in premenstrual tension syndrome. J. Clin. Psychiat., 1985;46, 436-437.

21. Giam, C. K. \& Teh K. C. Ilmu Kedokteran Olahraga. Jakarta: Binarupa Aksara. 1992

22. WHO/FAO 1985 yang dimodifikasi WNPG VIII. Pengelompokkan beban kerja berdasarkan proporsi waktu kerja, 2004.

23. Johnson, WG, et al: Macronutrient Intake, Eating Habits, and Exercise as Moderators of Menstrual
Distress in Healthy Women. Psychosomatic Med, 1995;57:324 - 30

24. Cowley MA, Smith RG, Diano S, dkk. The distribution and Mechanism of Action of Ghrelin in the CNS Demonstrates a Novel Hypothalamic Circuit Regulating Energy Homeostasis. Neuron (2003) 37:649-661 